удк

94(497)"1912/1913"(093.2)

341.3:061.23(73)"1912/1913"

Прегледни рад

Примљен: 17. 10. 2016.

Прихваћен: 16. 1. 2017.

Alexey TIMOFEEV

Institut for Recent History of Serbia al.timofev@gmail.com

Milana ŽIVANOVIĆ

\title{
Carnegie Report on the Causes and Conduct of the Balkan Wars 1912-1913. Could Report Authors and their Principals be Objective?*
}

\begin{abstract}
One of the first examples of using non-governmental organizations for creating "humanitarian reasons" in order to press upon the vulnerable states occurred in the Balkans a century ago. The Carnegie Commission on the Causes and Conduct of the Balkan Wars of 1912-1913 was a group of highly paid "impartial experts" engaged to investigate and find the results, which have already been known to the investigation customers
\end{abstract}

Key words: Balkan Wars, Carnegie Commission, propaganda warfare, Violation of war laws

Nowadays, nobody could be surprised by the fact that non-governmental organizations are used for creating "humanitarian reasons" in order to press upon the vulnerable states which are subject to external influence. Engaging a group of highly paid "impartial experts" to investigate and find the results, which have already been known to the investigation customers, is a common case for modern psychological war, when any action can be carried out in disguise of heightened concern for hu-

This article has been written within the framework of the scholarly project Tradition and Transformation - Historical Heritage and National Identity in Serbia in $20^{\text {th }}$ Century (№ 47019), financed by the Ministry of Education, Science and Technological Development Republic of Serbia. 
man rights, war crimes and crimes against humanity. One of the first examples of such manipulation occurred in the Balkans a century ago. We mean the Carnegie Commission on the Causes and Conduct of the Balkan Wars of 1912-1913. ${ }^{1}$

In Serbia, the activity of the Commission was estimated by contemporaries as a transparent propaganda campaign. ${ }^{2}$ In fact, in Serbia, the Commission Report is still perceived strictly in the context of military propaganda. $^{3}$ The Report content was well-studied and was the subject of many scientific discussions in Serbia. ${ }^{4}$ The global scientific attention was drawn to the Report after its republication by M. Abramowitz and G. Kennan in $1993 .{ }^{5}$ It was critically mentioned by M. Todorova, ${ }^{6}$ and embraced by others, ${ }^{7}$ such as N. Malcolm, T. Judah, G. Jacquignon, J. McCarthy, H. Sundhaussen etc. ${ }^{8}$ For example, M. Vikkers wrote "In 1913 an international committee including three Nobel prizewinners reported

1 International Commission to Inquire into the Causes and Conduct of the Balkan Wars, (Washington (DC): Carnegie Endowment for International Peace, 1914).

2 On what really drove Serbian soldiers and how they treated captured enemies or civilians in mass, see: Драгиша Васић, „Карактер и менталитет једног покољења“, Одабрана дела, (Београд: Altera, 1990); Хенрик Ангел, Када се један мали народ бори за живот, Српске војничке приче, (Београд: Итака, 1995).

3 Мирослав Свирчевић, „Пропаганда против Србије за време Балканских ратова и после њих 1912-1914. године“, Летопис Матице српске 3/2013.

4 Миле Бјелајац, „Провоцирање 'хуманитарне интервенције' против Србије 1913“, Балкански ратови 1912-1913: Нова виђења и тумачења, (Београд: Историјски институт - Институт за стратешке студије, 2013).

5 MortonAbramowitz, Preface,,"The Other Balkan Wars“, in:A1913 CarnegieEndowment Inquiry in Retrospect with a New Introduction and Reflections of the Present Conflict by George Kennan, (Washington (DC): Carnegie Endowment for International Peace, 1993).

6 Maria Todorova, Imagining the Balkans, (New York: Oxford University Press, 1997).

7 Detailed review of perceptions of the Carnegie Commission's Report: Igor Despot, The Balkan Wars in the Eyes of the Warring Parties: Perceptions and Interpretations, (Bloomington (IN), iUniverce, 2012); Predrag Simić, "Balkans and Balkanisation: Western Perceptions of the Balkans in the Carnegie Commission's Reports on the Balkan Wars from 1914. to 1996", Perceptions, Summer 2013, Volume XVIII, Number 2,113-134;

8 McCarthy Justin, Death and exile: the ethnic cleansing of Ottoman Muslims: 18211922, (Princeton: Darwin press, 1995); Tim Judah, The Serbs: history, myth and the destructuion of Yugoslavia, (London: Yale University Press, 1997); Noel Malcolm, Kosovo: a short history, (London: Papermac, 1998); François Grumel-Jacquignon, La Yugoslavie dans la stratégie française de l'Entre-deux-Guerres (1918-1935): aux origines du mythe serbe en France, (Bern: Peter Lang, 1999); Holm Sundhaussen, Geschichte Serbiens: 19.-21. Jahrhundert, (Wien: Böhlau, 2007). 
from northern Albania..." ${ }^{\prime 9}$ As we can see, there were neither three Nobel prizewinners among the members of the Commission during their mission in the Balkans, nor have they ever been to northern Albania... N. Akhund had done some profound research in Carnegie Endowment archives. ${ }^{10}$ She noted week points in the Report. In addition, she recognized that some articles from Greece on Bulgarian atrocities and on alleged Serbian deeds upon the Albanians, disseminated by Budapest correspondence, reached US and provoked some individuals in New York and Paris to respond by sending inquiry.

At the beginning of the $20^{\text {th }}$ century there was an idea that wars can be completely pushed out from the people's lives by improving international laws and creating supranational commissions. The International conference in Hague became one of the major international attempts to accomplish that idea. The first such conference was held with the active participation of the Russian empire in 1899 under the chairmanship of the Russian Ambassador in Great Britain E. E. Staal and was attended by 26 countries. The second conference took place in 1907 with the participation of 44 states under the chairmanship of the Russian Ambassador in France A. I. Nelidov. Neither the existing Pale of settlement, nor pogroms stopped the Russian Empire from speaking of international humanitarian law. Conferences in Hague adopted 16 conventions and 4 declarations on the ways of war prevention and warfare methods. It is symptomatic that the third conference did not take place because of the beginning of the World war in which the majority of the countries - participants of peace conferences acted on the opposite sides. After the outbreak of the war, most of conventions and declarations were violated. However, the adopted conventions and declarations had not been in vain, and were incorporated in structure of norms of international humanitarian law. Further, this law had little effect on the behavior of the superpowers in the warfare (in the period of World War II all participants of the conflict neglected it), but it became a useful instrument of propaganda giving legality to punishments of weaker and defeated sides. Mass resettlement of "the hostile people", practiced in the USSR, or the deliberate bombings of residential areas carried out by the USA and Great Britain in the years

9 Miranda Vickers, The Albanians: a modern history, (New York: St. Martin's Press, London: I. B. Tauris, 1995), 72.

10 Nadine Akhund, "An Unexpected Outcome of the Balkan Wars: The Carnegie Report of 1913", Балкански ратови 1912-1913: Нова вићења и тумачења, (Београд: Историјски институт - Институт за стратешке студије, 2013). 
of World War II have caused only criticism from historians, but were not publicly acknowledged as violation of the international rights. However, Arthur Harris who burned the peaceful German civilians in their own houses in 1942-1945, had already burned civilians of Pakistan and Iraq in the 1920s, "pacifying" the whole villages by incendiary bombs. At that time, it had not been officially recognized as a violation of international humanitarian law. Examples of free interpretation of what is and what is not a violation of international humanitarian laws can be found in abundance throughout the past $20^{\text {th }}$ century.

However, the idea of international humanitarian law, the idea of peace commissions, overseeing the humanity of wars and, as far as possible, preventing war emergence, was extremely popular among the educated and technocratic intellectuals, confident in the miraculous power of progress. One of those intellectuals was the famous Andrew Carnegie. An industrialist, financier and philanthropist, supporter of science and education, pursuing humanitarian and humane aims Carnegie was an interesting, broad and rather controversial person. Questions of participation of A. Carnegie in the backstage history of the Civil War in the USA and the campaign to wealth (in the conditions of "the wild West" capitalism which modern English-speaking researchers characterize by two expressive idioms "robber barons" and "dog-eat-dog") are far from our subject. We will not either speak about scandalous tragedies of Johnstown and Homestead. Within our subject the late years of A. Carnegie life are more interesting, when that naturalized in the USA Scot began to pay the increasing attention to charity "for the improvement of mankind". At first, a network of free public libraries was organized. In 1895, the Carnegie Institute in Pittsburgh was founded including a concert hall, exhibition gallery and the Museum of Natural History. Carnegie Institute in Washington and Carnegie Hall in New York were established. In total, A. Carnegie spent the incredible sum of 350 million dollars on charity, 288 million in the USA and the remaining 62 million in establishments on the territory of the British Empire. ${ }^{11}$

By the end of his life, A. Carnegie had lost interest in big business, and decided to fight "for peace in the world". At that time, Europe was the center of the world civilization, while the United States were rather far away from it. The USA was still quite provincial and fond of ideas of isolationism. Carnegie's ideas presented active steps towards elimination of

11 James A. Mackay, Little Boss: Life of Andrew Carnegie, (Edinbyrgh: Mainstream Pyblishing, 1997). 
that provincialism. However, his approach to the situation in Europe was quite peculiar. For example, up to the beginning of World War I, A. Carnegie considered the German Kaiser Wilhelm as the most peace-loving and respectable figure, supporting the consolidation of peace in Europe. So, on June $8^{\text {th }}, 1913$, on the occasion of the $25^{\text {th }}$ anniversary of the reign of the German Emperor Wilhelm, A. Carnegie "with pleasure and an honor" published the article "Kaiser Wilhelm II, Peacemaker"12 in the newspaper The New York Times beginning with the words: "The Civilized World This Day Bows reverently Before You..." There was only a year left before that peacemaker together with the other crowned heads of Europe would give the Royal assent to the unprecedented carnage of the First World War...

The Carnegie Endowment for International Peace was founded on November 25, 1910, timed to coincide with the 75th birthday of Andrew Carnegie. The first president of that Endowment was Elihu Root, a former United States Secretary of War, which soon (in 1913) was awarded the Nobel Peace Prize. Like nowadays peacefulness and nonparticipation in wars were not obligatory for Nobel Peace Prize laureates at all. Radical reforms were carried out under the leadership of Root in 1899-1904 in the Ministry of Defense, in the General Staff and in the military education system (e.g. West Point enlargement) that turned the American military machine from local instrument into the system capable to operate far beyond the territory of the USA. Under the leadership of E. Root all fruits of the Spanish-American War of 1898 were reaped, and the USA became the "classical" imperialistic state for the first time, having included Cuba, Guam, Puerto Rico and Philippines in its empire. In 1899-1902 the USA waged imperialistic war against the Philippine republic. The anti-imperialist league of the USA criticized the cruel suppression of the Philippine Insurrection. In response, E. Ruth declared that softness could only extend the crisis. ${ }^{13}$ The war against the Moro people in the southern Philippines (1899-1913) was so fierce that the US military came to the conclusion that .38 caliber pistols were insufficient and asked for .45 caliber pistols for the guaranteed killing of too resolute rebels. It is worth noting that in that war, which in fact was the first counterinsurgency war against the local rebel movements abroad for the US, the Sultan of the Ottoman Empire became the US ally. The Caliph (the head of the Sunni Muslims)

12 Andrew Carnegie, "Kaiser Wilhelm II, Peacemaker", The New York Times, June 8, 1913.

13 James R. Arnold, The Moro War: How America Battled a Myslim Insyrgency in the Philippine Jyngle, 1902-1913, (London, New York: Bloomsbyry Press, 2011), 171-172. 
Abdul Hamid II called the local population and their leaders to obey the US, so the Americans were strengthened due to the Sultanate of Sulu..$^{14}$ In fact, this event promoting strengthening of the American army became the first major US foreign policy achievement of its own diplomacy, important for foreign policy of the USA in the Balkans. ${ }^{15}$ Besides elimination of threat of jihad against the American troops, the Sultan's intervention led to the fact that local Muslims did not support the struggle of the Philippine republic for independence from the USA. Those events naturally created the most positive attitude of E. Ruth towards the Ottoman empire as during his tenure as the US Minister of War in 1899-1904, and later as State Secretary in the 1905-1909.

In the period of the Balkan Wars the sympathy of A. Carnegie Endowment management to the Ottoman Empire and Germany ${ }^{16}$ quite unambiguously led to vigilance to the Balkan union and especially to those countries which had no close relations with the central powers. Many Western European countries vigilantly watched the Ottoman Empire weakening on the Balkans in the result of the Balkan Wars. Citizens of those countries were also included in the Carnegie Commission that naturally caused the cautious relation of the Commission to the Balkan question. The special correspondent of London Times Cyril Campbell who visited Serbia and Bulgaria in the years of war gave the quintessence of this interpretation of the Balkan question in his work The Balkan Wars Drama:

The Balkan Problem originally had nothing whatever to do with Turkey. It arose solely and entirely from the jealousies and rivalries of the minor States and of the two great protagonists, Austria and Russia. ${ }^{17}$

14 Idris Bal, Turkish Foreign Policy in Post Cold War Era, (Boca Raton (Flo.): Brown Walker Press, 2004), 405-406.

15 John P. Finley, "The Mohammedan Problem in the Philippines", The Journal of Race Development, Vol. 5, No. 4 (Apr., 1915), 353-363.

16 Those sympathies disappeared after the beginning of the World War I, when the USA interests became opposed to the interests of the Central Powers and their allies. A special importance was given to the Root commission in Russia in 1917, which had the aim to support the active participation of Russia in the war as both the Tsarist government and the Bolsheviks obviously did not want to take part in the world massacre any longer and were looking for the way to the separate peace. The American peacekeepers preferred the position of the provisional government which was actively seeking to continue the war. David Mayers, The Ambassadors and America's Soviet Policy, (London: Oxford University Press, 1977), 67-80.

17 Cyril Campbell, The Balkan Wars Drama, (New York: McBride, Nast \& Co., 1913), 3-4. 
Such views on the events of the Balkan Wars were natural for the Western European countries, reasonably perceiving Reconquista, Charles Martel's activities and the Battle on the Catalaunian Fields as long-forgotten relics of the Middle Ages. But for the Balkan people and for the closest European neighbors of the Ottoman Empire (Austria and Russia) the battle with the green banner of Islam and defense of brothers in faith under the power of Muslims were not so remote past. Unlike the British, French, Belgians and Americans, these people have not considered colonial interests in wars with Muslims as dominant. That is why the report of the Balkan Commission of Inquiry (the International Commission to Inquire into the Causes and Conduct of the Balkan Wars) which, in addition, did not have any official status, couldn't be attractive or objective in the opinion of the Serbian government or citizens. It is worth noting that the general vigilance towards the unknown media was promoted by the active information and propaganda operations developing in parallel with the Balkan Wars. Educated contemporaries of the Balkan Wars were acutely aware that

...the first and primary object of a belligerent nation is to try and convince the world that the enemy is using or planning to use every dirty underhand trick which could be devised by the human brain. To disseminate this news the agents or representatives of that nation do not hesitate to make use of the Press of a neutral and supposedly impartial people, a Press which in many cases is represented locally by those who have the very best reasons for not being impartial themselves. ${ }^{18}$

In those circumstances, the role of a Russia's representative in the Commission increased since he could (or could not) become a bridge to the perception of the whole Commission as a board, deprived of bright anti-Serbian coloring though a self-proclaimed one. Unfortunately, it is necessary to state that P. N. Milyukov failed to become such a bridge. Moreover, in fact he was perceived in Belgrade as a negative marker of the entire Commission. The Commission activities were appreciated in Belgrade through the prism of Milyukov image. Therefore, it is necessary to say something about this Russian scientist, politician and public figure.

$18 \quad$ Ibid., 181. 
A descendant of a noble but impoverished family, a graduate of the Moscow University Pavel Nikolaevich Milyukov was a person of natural humanitarian talents. In 1877, he finished the 1-st Moscow grammar school with honours, many other stars of Russian historical science (e.g., M. P. Pogodin, S. M. Solov'ev) also finished that school. Studying at the faculty of history and philology of the Moscow University, the oldest university in Russia, became natural continuation of his education. As well as any humanitarian, young Milyukov kept abreast of current social trends. While studying at the grammar school, Milyukov was a member of Slavophile society, and in the period of the Russian-Turkish war of 1877-1878 he even went to the Caucasus for three months during his summer holidays, where he helped to keep records of the Moscow sanitary unit. According to the spirit of the time, the student P. N. Milyukov passed from reading of Slavophiles' books (K. Aksakov and N. Danilevskiy) to the slight left opposition and reading of liberal literature. He was expelled from the university for taking part in student riots, had to interrupt his studying and went to Italy for the academic trip, but later he was readmitted and allowed to take his degree. In spite of all these troubles in 1883 Milyukov received a certificate of good behavior and excellent success. The dean of the faculty, the well-known historian - slavicist Nil Popov and the famous historian - specialist in the Russian history V. O. Kliuchevskiy recommended toemploy P. N. Milyukov as an assistant professor at the faculty. Slightly liberal and oppositional political views were useful for an academic career in the imperial Russia. ${ }^{19}$ But at that moment the idyllic path from an assistant professor to full professor's chair was interrupted by some unforeseen obstacles. Whether it was a classical academic quarrel between V. O. Kliuchevskiy and P. N. Milyukov (who had allegedly incited students to lampoon the aged colleague), or whether there was an unfortunate set of circumstances, but the cup of the authorities' patience was overflowed and some slightly oppositional hints of Milyukov at his next public lecture were considered to have definite political intentions. ${ }^{20}$ The career of the promising assistant professor was destroyed - he was fired from the Moscow University and banned from living in the capitals (university cities). Of course, it was not the end of his academic career, but the career was slowed. Having to leave the university students, the exciting passion of public work and

19 Александр В. Макушин, Павел А. Трибунский, Павел Николаевич Милюков: труды и дни (1859-1904), (Рязань: Частный изд. П. А. Трибунский, 2001), 20-104.

Ibid., 130-150. 
the heady energy of social activity, and admiring girl students, was hard for the successful associate professor in the prime of his life. Milyukov has gone to provincial Ryazan' where he felt extremely bored despite all his attempts to apply his knowledge and talents. He vainly tried to justify himself and to prove his loyalty to the authorities, addressing the Ministry of Internal Affairs. With the help of his friends, Milyukov tried to refute charges of his political influence on students. As a result, November $6^{\text {th }}, 1896$ the case was decided in administrative proceedings and Milyukov was sentenced to the expulsion beyond capitals and university cities for two years. At that period, P. N. Milyukov was lucky to get a nice chance to escape from the provincial environment - he received the invitation to lecture at the Higher School in Sofia. So, the assistant professor left the drowsy Ryazan', acquired the exit visa and hurried to Bulgaria. In 1897 his wife and two young children joined. Milyukov plunged into the Balkan world at the turning point of the history of the Balkans (however, the turning points are characteristic of local history). Bulgaria renewed and strengthened relations with Russia in 1896, after a decade of conflict under the rule of St. Stambolov. The heir apparent Boris converted to Orthodoxy, amnesty of Russophile emigrants was carried out; Russia restored full diplomatic relations with Bulgaria. At the same time, in Serbia, certain events were cooling the communication with Russia - the persecutions of the radicals, the return of the king Milan, whose behavior towards his spouse and his country caused a strong aversion of the public opinion in Russia.

In those circumstances, the arrival of Milyukov to Sofia became his benefit. Actually, P. N. Miliyukov could not have read a course of lectures up to the end at the higher school, so he started reading them in Russian. Soon, at the insistence of the Russian Embassy, he was dismissed from the University for the demonstrative refusal to participate in the reception, devoted to the Emperor's birthday, and for inciting the students to anti-Russian actions. But according to the terms of the contract, within a year he continued to receive payment at a rate much exceeding salary of a regular Bulgarian professor. In addition to the solution of his financial problems, Milyukov found the friendly intellectual environment in Bulgaria. The scholar, expelled from his native school, was warmly welcomed by I. Shishmanov, A. Malinov, P. Karavelov, L. Miletich, I. Georgov. Sympathies for Russia along with the hostility to the Russian officialdom were typical for the left intellectual environment in Sofia, which obviously favorably impressed Milyukov. On the other hand, sharp nationalist 
feelings concerning the Bulgarian interests in Macedonia and hostility to the Serbs could not but enter the cognitive map of the scientist. ${ }^{21}$ The best proof of the importance of "Bulgarian motives" in the Milyukov's views could be an event that occurred with this elderly scientist at the end of his active political and academic career. On Milyukov's $70^{\text {th }}$ anniversary the Bulgarian government presented him with a generous cash reward of 270 thousand Bulgarian levs, which allowed him to buy a villa in the south of France to spend there the last years of his life. ${ }^{22}$

In his articles and scientific papers P. N. Milyukov was more and more biased in assessing the developments in Macedonia, which could not escape from the eyes of those readers who did not share his views. ${ }^{23}$ The peak of this bias were, of course, the cartographic works of Milyukov, among them a Boué's map which Henry Robert Wilkinson called the best specimen of "the pro-Bulgarian propaganda" and whose distribution was later put to good use by the Bulgarian 'revisionists'.

His map was incorporated, for example, in P. Milyukov's pro-Bulgarian work on ethnographic maps published in 1900, and it formed part of D. Rizov's atlas produced in Berlin in 1917. Indeed, Boués map put the Bulgarian case in such a favorable light that in 1918 A. Belić, the distinguished professor of Slavonic languages at Belgrade, was forced to make Boués map the subject of a special article, in which he endeavored to explain away the pro-Bulgarian views adopted by the latter. ${ }^{24}$

Another Bulgarian propagandist map (Kănčev's map) was included by P. Milyukov in the atlas in 1900 and later in the Carnegie Report, Inquiry into the Causes of the Balkan Wars (1914).

21 Павел Н. Милюков, Воспоминания (1859-1917), (Москва: Политиздат, 1991), 125-135.

22 Русское зарубежье. Золотая книга эмиграции. Первая треть ХХ века. Энциклопедический биографический словарь, (Москва: Российская политическая энциклопедия, 1997), 415-417.

23 Павел Н. Милюков, „Письма из Македонии“, Русские ведомости, 1898-1899; Павел Н. Милюков, „Из поездки в Македонию (Европейская дипломатия и македонский вопрос)“, Вестник Европы, 1899, № 5; Пять этнографических карт Македонии с текстом П. Н. Милюкова, (Санкт-Петербург: Издание Школьной Картопечатни, 1900).

24 Henry R. Wilkinson, Maps and Politics: A Review of the Ethnographic Cartography of Macedonia, (Liverpool: University Press, 1951), 39. 
In both cases it represented the official Bulgarian view of ethnic conditions in Macedonia. In the first place it re-emphasized Bulgaria's traditional rights in Macedonia, and secondly it gave weight to the idea that the Albanians were the most important minority in the north and west. ${ }^{25}$

In this case, it certainly did not mean any kind of "love" for Bulgaria. It is more likely that Milyukov, in "his westernized denial of nationalism have lost the interest in the Slavic communication at all." After a year of living in Sofia, Milyukov wrote: "My respectable colleagues have managed to poison my stay here so, that the insistence of the agent [concerning Milyukov's dismissal from the University of Sofia - A. T.] is a kind of coup de grace". In a quick temper he exclaimed that "after a year of contacts with Bulgarian brothers he would not regret at all if he had to liquidate all his affairs here". His wife, A. S. Milyukova, made even more categorical statement and spoke about the harmful influence of "the Bulgarian spirit on local Russian women as there they became callous, selfish and self-serving." ${ }^{26}$

Actually, the Milyukov's choice of the Balkan country which he "supported" had not been caused by definite profound knowledge or his own preferences. It is possible to state that Milyukov just made a contrary choice, as in his own words, the official policy of Russia emphasized the importance of Slavic question with special emphasis on Serbia. The pejorative characteristic given by Milyukov to new Russian Minister of Foreign Affairs S. D. Sazonov is eloquent and revealing:

In the Slavic question, as I could see later in personal intercourse, he held the official views of that time and was entirely in the hands of the old politicians of the same type as our representative in Belgrade Hartwig, an ardent fanatic of Slavophile tradition. Sazonov shared, of course, the one-sided preference for the Serbians - Russian old clients to new the Bulgarians, and the faith in safety of Russian prestige in the Balkans, and the traditional view of the providential role of Russia among the Slavic peoples. ${ }^{27}$

At the same time, in Milyukov's opinion, the largest part of ruling Russian elite of the early $20^{\text {th }}$ century and Nicholas II himself regarded

25 Ibid., 131.

26 Макушин, Трибунский, Павел Николаевич Милюков, 186, 191, 193.

27 Милюков, Воспоминания, 347-348. 
Bulgaria attentively, negatively estimating its monarch Ferdinand. ${ }^{28}$ In those circumstances it was natural that Milyukov (as well as many other Russian oppositional liberal politicians) looked at the situation in the Balkans from the absolutely opposite point of view. Undoubtedly, his contacts with the official Bulgarian institutes, with the Macedonian pro-Bulgarian revolutionaries and komits before the Balkan Wars and during the First Balkan War, his active pro-Bulgarian position made the figure of Milyukov quite unsuitable for objective investigation of the situation during the Balkan Wars. ${ }^{29}$ The objectivity of Milyukov was unlikely strengthened by the fact that his trip to the Balkans during World War I was initiated by his "old friend Charles Crane, the usual admirer of old cultures and the supporter of the liberated peoples. It was later said that he had given financial support to the Albanians..." ${ }^{30}$ Milyukov's trip took place just in connection with the Albanian Uprising. The figure of Charles Crane is not less interesting than A. Carnegie or E. Ruth. He was an American millionaire, who had great interest in politics and international affairs. Crane had already materially supported Milyukov earlier. In the frame of this work we would only state that Crane gave active financial support for lecturing at the University of Chicago not only to Milyukov, but also to M. M. Kovalevskiy and Thomas Masaryk. He took part in the mission of Ruth in Russia in 1917-1918, visited the East Europe and Russia many times. However, affection for "the enslaved people," impressions of the Russian revolution and sympathy for Muslims drove him to open anti-Semitic views. ${ }^{31}$

This detailed insight into the biography of Milyukov is necessary here not only because Serbia perceived activities of the Commission on the basis of attitude to Milyukov as an obviously biased figure, but also because his personality was essential in the work of the Commission. Naturally, Milyukov was known in the Balkans as a bias politician, which ensured him a positive attitude in Bulgaria, but hostility in Serbia and Greece, as he later recalled. ${ }^{32}$ At the beginning of June 1913, Serbian newspapers published some articles under the expressive titles describing „daring attacks of a person who received money from the Bulgari-

\footnotetext{
28 Ibid., 356.

29 Ibid., 135, 356.

30 Ibid., 351.

31 Erik Larson, In the Garden of Beasts: Love, Terror, and an American Family in Hitler's Berlin, (New York: Crown Pyblishing Groyp, 2011), 38-39.

32 Милюков, Воспоминания, 353.
} 
ans ${ }^{\prime \prime 3}{ }^{33}$ Interestingly, the information about the Bulgarian attack on Serbian army at night of June 11-12, 1913 was published on the same page with one of such articles, where Milyukov was mentioned in the same context of "Bulgarian mercenary." The article was retelling the report of Count Bobrinsky about Milyukov's speech, which stated that "Milyukov adhered to the Bulgarian point of view in the narrowest sense of the word," that "Milyukov's speech was very good advocating summary of the Bulgarian views and the Bulgarian interests," and that his apology for Albania as the safe country for the stability of the Balkans was questionable. $^{34}$

According to the recollections of Milyukov, four persons really participated in the activities of the Commission

...the old man Dutton, a venerable teacher, a professor at Columbia University; deputy chairman Godard, a lively energetic and dedicated man; and the two of us, Brailsford and me, the only real members of the Commission familiar with the aspirations and languages of the Balkan peoples. ${ }^{35}$

Who was that Brailsford? Henry Noel Brailsford was an English journalist, who had visited the Balkans at the time of major conflicts in 1897,36 after the events of 1903 he wrote about the Bulgarian komits' activities in the European part of Turkey with sympathy. In 1906 he published the book on Macedonia which in fact demonstrated close to Milyukov's sympathies in the Balkans question, but in slightly more extremist expressions. ${ }^{37}$ In October 1904 Brailsford was a mediator in buying British passports for members of Socialist Party, terrorists Boris Savinkov and Maximillian Schweitzer. Having arrived with the English passport to St. Petersburg, Schweitzer was engaged in preparation of the explosive devices intended for terrorist attacks. On March 11 ${ }^{\text {th }}, 1905$ the spontaneous explosion in the hotel killed Schweitzer and broke his body into pieces. Fortunately, there were no victims among hotel guests and employees. Upon the demand of the Russian government, England started investigation of Brailsford activities, but he got off with only a 100 pounds penalty for forgery. In May 1907, Brailsford helped fund-raising

33 Аноним, „Миљуков против Србије“, Правда, 55, 8. 6. 1913, 2.

34 Аноним, „Говор графа Бобринског“, Правда, 160, 13. 6. 1913, 2.

35 Милюков, Воспоминания, 361.

36 Henry N. Brailsford, The Broom of the War-god: A Novel, (London: William Heinemann, 1898).

37 Henry N. Brailsford, Macedonia; its races and their future, (New York: Arno Press, 1906). 
for the organization of the V Congress of the Russian Social Democratic Labour Party in London. It is interesting that in the years of World War I Brailsford was not just a left pacifist, but adhered to the pro-German views. In the interwar period, he actively criticized the Versailles system and sympathized with the USSR, but abandoned these sympathies after the beginning of the Soviet-Finland war. ${ }^{38}$

The arrival of the Commission to Serbia was described in the memoirs of the first Secretary of the Russian mission in Belgrade Vasiliy Nikolayevich Shtrandtman, who did not like the Russian Ambassador in Belgrade Nicholas Genrikhovich Hartwig and was rather an objective author that added credibility to his perception of the occurring events. ${ }^{39}$ Judging by these memoirs, the arrival of "a faithful devotee of Bulgaria Milyukov" to Serbia as a member of an international public commission was a wellknown and unpleasant event which the Russian diplomatic mission had tried to prevent in any possible way because it threatened to turn into a scandal. Before the arrival of the Commission, any data on war crimes committed by Serbs were qualified as malicious slander and hostile propaganda. However, the attempts to prevent the arrival of P. N. Milyukov through the Russian Ambassador in Paris A. P. Izvolsky were not made at all or were not successful. In Serbia, the information about the Commission's work was published on August, $8(21) .^{40}$ In Serbian press the Commission was called "a Parisian commission on investigation of the Bulgarian crimes," its activity was not perceived hostilely and the only name mentioned was the envoy of Reichsrat, the Austrian professor Josef Redlich. ${ }^{41}$

The members of the Commission arrived to Belgrade by August $10^{\text {th }}\left(23^{\text {rd }}\right), 1913$. The Serbian press immediately informed the readers about that event. ${ }^{42}$ Next day after the arrival, P. N. Milyukov had a sharp conversation with the ambassador who criticized him for his speech in the State Duma, which had been far from objectivity and contained attacks to N. G. Hartwig himself. The Ambassador also notified Milyukov

38 Fred M. Leventhal, The Last Dissenter: H. N. Brailsford and His World, (Oxford: Clarednon Press, 1985); Борис В. Савинков, Воспоминания террориста, (Ленинград: Лениздат, 1990).

39 Василий Н. Штрандтман, Балканские воспоминания, (Москва: Книжница, 2014), 205.

40 Аноним, „Истрага у Маћедонији“, Политика, 3437, 8. 8. 1913, 3.

41 It was mentioned that Austro-Hungarian government denied permission for his traval to the Balkans.

42 Аноним, „Истрага у Маћедонији“, Политика, 3441, 12. 8. 1913, 3. 
about the undesirability of his stay in the country because "Serbians did not wish to deal with him, did not trust him at all... Pašić would not meet him." Thus, the Commission did not work in Serbia as the result of public and government obstruction. That was actually due to Milyukov, whom local public opinion perceived as the enemy of Serbia. It is worth noting that N. Pašić agreed to meet with the members of the Commission under the condition that Milyukov was not present at the meeting, as the Serbian government refused to collaborate with him. But the Commission denied that proposal and decided to leave Serbia.

On the eve of the Commission departure, in the evening of August $12^{\text {th }}\left(25^{\text {th }}\right)$, an even more unpleasant incident occurred at the restaurant of the luxurious hotel "Moscow" belonging to the Russian insurance company "Russia" where the members of the Commission were accommodated. Milyukov recollected later:

We were sitting downstairs at the restaurant; the protesters, mostly patriotic youth, gathered around us at the separate tables. A sign was given and rough shouts and sharp speeches sounded to the address of "the enemy" of Serbia... I felt bitterness of undeserved insult and impossibility to explain anything to that youth... In the early morning all of us left for Thessaloniki. It was my last visit to Belgrade. ${ }^{43}$

That very unpleasant incident was described by the Serbian press with great pleasure. In a special article they informed their readers that

The famous slanderer of the Serbian people Milyukov was thrown out from the hotel "Moscow". When he appeared in the hotel "Moscow" after his dinner, the public began to whistle and demand that Milyukov clear off. As a result Milyukov went to his room and had to leave in the morning. ${ }^{44}$

This incident was so unpleasant, unexpected and humiliating for Milyukov that in his memoirs, trying to create an image of objectivity in his relations with Serbia, he remembered some Serbian friends who had come to say goodbye to him in the hotel and hotly stood up in his protection during the demarche. According to P. N. Milyukov, he was saved by a "Montenegrin Venović" with "Professor Ljuba Jovanović" also being present there. ${ }^{45}$ In his memoirs, V. N. Shtrandtman clarified the situation.

43 Милюков, Воспоминания, 361.

44 Аноним, „Избачен Миљуков“, Правда, 221, 13. 8. 1913, 3.

45 Милюков, Воспоминания, 361. 
According to his information, the hapless visitant expert on the Balkans was saved by

an appointed by N. Pašić official of the Ministry of Foreign Affairs Cemović, whose task was to warn Milyukov about possible hostile actions of military and youth in case of his public appearances in the restaurants or in the streets. In the evening on August 25, in the presence of Cemović and the former minister Ljuba Stojanović... a group of protesters approached them at restaurant "Moscow". One of the protesters began to read aloud the spiteful Milyukov's article about Serbia, and then they all together in chorus demanded his removal from Belgrade. Cemović tried to calm the crowd, meanwhile Milyukov managed to leave the hall. ${ }^{46}$

In fact it is clear that the rescuer was not any friend from Montenegro, but a Serbian diplomatic official, who tried to prevent an objectionable scandal that could have happened if a citizen of Russia, the deputy of Duma, had been beaten in the friendly city of Belgrade. V. N. Shtrandtman stated that N. Pašić regretted the incident, but did not feel himself responsible for it because Milyukov had been warned. Needless to say that Pašić had no confidence in him and could not feel any confidence, knowing how biased and tendentious Milyukov was in transforming his, Pašić's, words ... i.e. lied. ${ }^{47}$

Echoing the official line, the Serbian press expressed hostility towards P. N. Milyukov, but condemned a spontaneous act of the youth incited by "Solarović" who had collected young men that surely would have punched the Moscow expert "if some serious people had not interfered." ${ }^{48}$ Obviously, that unique for traditionally Russophile Serbia incident concerned the public and a week later the Serbian press hurried to inform its readers about the reaction of one of the Russian newspapers to the incident in the article, beginning with the expressive statement "It served him right!" 49

After the departure of the Commission members, Serbian semi-official press specified the opinion of the Serbian government and society

46 Штрандтман, Балканские воспоминания, 206.

47 Ibid.

48 Аноним, „Напад на Миљукова”, Вечерње новости, 215, 13. 8. 1913, 2.

49 В[рбава]-ц, „Руси о Миљукову“, Вечерње новости, 221, 19. 8. 1913, 1. 
about the Commission in general. ${ }^{50}$ The article was published on the first page as an editorial that gave it more importance. The article emphasized the unacceptability of the Commission due to the inclusion of Milyukov and connected the Commission activity with the aspirations of "the enemies of the Balkan independence, and in the first place of Austria-Hungary, who has been deceived in their expectations", and whose press eagerly relished the Bulgarian propaganda. The author of the article did not name other beneficiaries of the Commission activity. However, it was stressed that Serbia should express its negative attitude not only to the most unsympathetic member of the commission (P. N. Milyukov), but also to the Commission work in general. The popular newspaper Politika informed its readers about the details of the short-term stay of Carnegie Commission in Serbia. The author of the article reported that the Commission had not been accepted either by the King or by Pašić, but only by the Chief of the Secretariat of the Ministry of Foreign Affairs D. Stefanović. He warned the Commission members that P. N. Milyukov was an obviously prejudiced person, who had been acting as the biased man for many years, and could not hope for any cooperation with official authorities of Serbia as he "would not be able to judge impartially". At the same time the author of the article referred to the French Le Temps which doubted the objectivity of the second expert in the Balkans from the Commission, H. N. Brailsford who "had been playing the part of a systematic defender for ten years if not to tell the semi-official lawyer of the Bulgarian views before the English public ${ }^{\prime 51}$ With great pleasure, the Politika continued the theme of the Commission in the following issue. Reporting that Professor Redlich could not have participated in the work of the Commission, the newspaper assumed that he had "renounced the society of Milyukov and Brailsford". ${ }^{52}$ Milyukov discrediting the work of the whole Commission was unacceptable and also underlined by the radical party newspaper Samouprava. ${ }^{53}$

Nevertheless, P. N. Milyukov whose views had been "warmed up" by a meeting in Belgrade, according to his Memoirs, had done half of work of the Commission on collecting data (about the Serbian-Greek-Bulgarian relations in Macedonia) while H. N. Brailsford got the Greek-Turkish part. P. N. Milyukov claimed that he had written also not less than a quarter of the final text of the report.

50 Аноним, „Карнеџијева комисија“, Правда, 223, 15. 8. 1913, 1.

51 Аноним, „Миљуков и компанија“, Политика, 3442, 13. 8. 1913, 3.

52 Аноним, „Истрага у Маћедонији“, Политика, 3444, 15. 8. 1913, 2.

53 Аноним, „Г. Миљуков - маркиран!“, Самоуправа, 185, 13. 8. 1913, 1. 
Serbian newspapers gladly relished the details of the boycott towards P. N. Milyukov throughout his way. The Serbian media emphasized that in Skopje nobody wanted to see Milyukov nor even talk to him, "except the holder of an inn where he was staying, and the chief of the railway station who had told him the departure time of the train to Thessaloniki." 54 The Serbian press called Milyukov a "hostile to the Serbian people Slav" and continued to remind the public about his actions and words before and during the conflict with Bulgarians. ${ }^{55}$

At the same time, not only the Serbs but also Greeks (following the advice of Belgrade and Paris) demonstrated hostility to Milyukov up to the full boycott of his person because of his pronounced pro-Bulgarian point of view.

As early as on August $18^{\text {th }}$, the Thessaloniki governor transferred the Commission the order to leave Thessaloniki. I was also mentioned there; but the main Greece "enemy" happened to be Brailsford, a participant of the struggle for the Crete liberation and the person objectionable to the Athenian government. ${ }^{56}$

The Belgrade newspapers wrote about the British journalist in details, specifying the charges in publishing pro-Bulgarian articles and the membership in Bulgarophile Balkan Committee in London. ${ }^{57}$

Apparently, it was known in Athens, and that was the reason why H. N. Brailsford prudently did not go there. In Athens, P. N. Milyukov was also thrown out from the hotel almost immediately after the article in the press informing the readers that the notorious "enemy of Greece" had arrived to Piraeus. However, according to his memoirs, P. N. Milyukov spent even those few days not in vain but for "the tourist purposes." Watching those events, Serbian media reported briefly that the Greek government did not express any confidence in P. N. Milyukov either, and as the Commission insisted on his participation, the government refused to cooperate with the Commission at all. The author of the article in Politika regarded boycotting Milyukov in Greece as the "event forcing to perceive the work of the Commission as absolutely valueless." ${ }^{\text {58 }}$ Diminishing

\footnotetext{
54 Аноним, „Миљуков у Солуну“, Правда, 225, 17. 8. 1913, 3.

55 Врбавац, „Миљуков“, Вечерње новости, 219, 17. 8. 1913, 1.

56 Милюков, Воспоминания, 361-363.

57 Аноним, „Свирепства на Балкану“, Вечерње новости, 226, 24. 8. 1913, 2.

58 Аноним, „Миљуков у Грчкој“, Политика, 3448, 19. 8. 1913, 2.
} 
the value of Commission's work became a commonplace in other Serbian editions too. ${ }^{59}$

But that apparently seemed not enough, so the Serbian newspapers published one more article subtitled "Now we see what kind of investigation was in Macedonia!" Retelling the article of the Le Temps correspondent from Solun, the author explained in detail the double standards and the pro-Bulgarian point of view of Milyukov and Brailsford. He opposed their views to the positions of Godard and S. Dutton who had no prejudices about the Balkans before the arrival. The article mentioned also Milyukov's attempts to discredit the French commission which had already visited Macedonia to investigate the events. The horrible statement was attributed to $\mathrm{H}$. N. Brailsford, that "he will believe in the Bulgarian atrocities only if some mutilated corpses are shown to him and brothers or sisters of the dead people testify that they are the victims of Bulgarians." It was also reported that Milyukov, looking at pictures of Bulgarian komits, participants of the atrocities, exclaimed: "But I do not see a single familiar face here!"60 At the same time, the official Serbian position remained unchanged. As it was formulated by the State press bureau:

The Serbian government declares categorically that it is not against the idea of a commission of inquiry, but the opposite - its purpose is the investigation (...) if the work of the commission has failed, it is because one of its members is an open enemy of Serbia and Greece, which is known for what he wrote and did. ${ }^{61}$

After that failure, Milyukov left Greece for Turkey where Mehmed Talaad-Pasha was the Minister of Internal Affairs. He was one of Milyukov's old friends from the circle of „Young Turks“. After fruitful work on collecting the information in Turkey, Milyukov left Istanbul for Sofia where he could finish collecting the data which served as a basis for writing the chapters of the Commission Report.

In fact, only in Turkey and Bulgaria members of the Commission were accepted at the highest governmental and public levels. Both countries supplied the Commission with large quantity of the propaganda material. But the Bulgarian information naturally dominated. As Milyukov stated in his Memoirs, the personal car of the Minister of Internal Af-

59 Аноним, „Међународна комисија за мир“, Самоуправа, 189, 19. 8. 1913, 2.

60 Аноним, „Миљуков у Солуну“, Политика, 3451, 22. 8. 1913, 2.

61 Аноним, „Истрага свирепстава“, Вечерње новости, 227, 26. 8. 1913, 2. 
fairs of Turkey with an adjutant drove him to the border of Bulgaria and Turkey, where the assistant professor took the train specially sent for him. Milyukov's version of those events was contradicted by the Serbian article which reported that "a notorious Serb-hater" had went incognito through Niš on September 29 $9^{\text {th }}, 1913 .^{62}$ In Bulgaria, the Commission was working from August $31^{\text {st }}$ to September $10^{\text {th }}$ when its members breathed a sigh of relief and left for Paris. The Bulgarian government strongly supported activity of the Commission in every possible way both at the internal, and at the international level, that was emphasized by the Serbian press at every opportunity, publishing foreign messages on this subject. $^{63}$

P. N. Milyukov recalled:

... in Sofia, our work was arranged quite differently

than in three other countries we visited. We were officially and solemnly recognized, but even the Bulgarians, who were the first to raise the question about the investigation of "atrocities", did not expect our arrival and had not prepared the material for us. And I have to admit, all this preparation was made completely impartial and non-party... A large part of the documents and testimony had been prepared for us beforehand; the other part was delivered immediately upon our request. Preparatory work was mainly made by my old friend Professor Miletich and I could not have the slightest doubt in his absolute honesty and conscientiousness... ${ }^{64}$

No need to comment, indeed! ${ }^{65}$ No objective researcher can believe in objectivity of "information" collected by one of the conflict parts during the military actions or just after their end. There are little useful information for objective historian in the Report. This limited amount

62 Аноним, „Миљуков у Нишу“, Правда, 239, 31. 8. 1913, 2.

63 Аноним, „Свирепства на Балкану“, Вечерње новости, 229, 29. 8. 1913, 2.

64 Милюков, Воспоминания, 363-364.

65 Maybe only the personality of L. Miletić who acted on behalf of Bulgarian cause requires some additional notes. He was a son of Djordje Miletić native brother of Serbian politician Svetozar Miletić. Once, Serbian government sent him to Štip to run a Serbian school. He shifted his Serbian attitude and affiliation for Bulgarian one. His son soon became more ardent Bulgarian nationalist than his father was. He was a famous author of political pamphlets, "applicated" historian. Любомир Милетич от Щип, Вардарска Македония - Гръцките жестокости в Македония през Гръцкобългарската война, (София: Държавна печатница, 1913); Любомир Милетич, Разорението на тракийските българи през 1913 година, Българска академия на науките, (София: Държавна печатница, 1918). 
of data could be, in the light of posterior sources, regarded as valid (for instance the part (VI) on Economics Results of the Balkan Wars or listed (official) documents in Appendix $\mathrm{H}$ or others in relation to previous chapters). The Serbian press immediately reported about the Commission arrival to Sofia and briefly informed that on the $1^{\text {st }}$ of September, the members of the Carnegie Commission had come to Sofia and began working "in hands of impartial Bulgarians." 66 The Serbian newspaper Politika continued its virtual discussion with Carnegie's Commission by the publication of five Bulgarian documents with annotations and with sarcastic comments that meanwhile as such documents were being found in the trophies, "the Carnegie Commission, expelled from Serbia and Greece, conducted investigation in Sofia against Serbians and Greeks in favor of Bulgarians." 67

Hostility towards the Commission was expressed even in poetic form. In the poem "Reliable Expedition" in Pravda the anonymous author noticed with irony that after the activities of the Carnegie Commission in investigation of crimes, it is necessary to investigate crimes of Milyukov in the Balkans. ${ }^{68}$ The editorial in Politika was to become the final volley of the cannonade of the Serbian press to the Carnegie Commission. The anonymous author called the Commission arrival to Sofia "the last act of the comedy", once again expressed doubts in both its experts (P. N. Milyukov and H. N. Brailsford whom he called "Milyukov for Greece"), mentioned disagreements between them and the "uninformed members of the commission" and rhetorically asked a question how much it was possible to trust members of the commission who had been expelled from everywhere except Sofia where they would collect all evidence. ${ }^{69}$ After this devastating text, it was necessary to report shortly that the Carnegie Commission members left the Balkans and that was done. ${ }^{70}$

And yet, the incident with the Commission had a scandal continuation. It was connected with the name of Samson Chernov, ${ }^{71}$ a Jewish photographer and cameraman, a Russian citizen, a talented film artist and journalist, whose works were published in Russia and in France. His

66 Аноним, „Карнеџијева комисија“, Правда, 241, 2. 9. 1913, 2.

67 Аноним, „Документи о Бугарима“, Политика, 3463, 3. 9. 1913, 1.

68 Аноним, „Епиграм 'Сигурна експедиција'“, Правда, 243, 4. 9. 1913, 2.

69 Аноним, „Миљуков и другови“, Политика, 3464, 4. 9. 1913, 1.

70 Аноним, „Карнеџијева мисија“, Политика, 3467, 7. 9. 1913, 2.

71 Саша Ружесковић, „Трагом Самсона Чернова“, Весник. Часопис за историју, музеологију и уметност 38/2011. 
abundant photo-reports about the period of the Balkan Wars were used not only in newspapers but also as photo exhibitions about the events. His pro-Serbian point of view was beyond any doubts, he demonstrated his views in public lectures and documentary articles about the Balkan wars. Probably, journalist Chernov, as well as assistant professor Milyukov, was also on the "salary", but in Belgrade, not in Sofia. According to S. Chernov, during his stay in Paris in the fall of 1913, Milyukov addressed him with the request to have a meeting. When they met, Milyukov suggested S. Chernov to pass all his notes and photos under a condition of full transfer of rights, i.e. the actual termination of their public use, their selections and destruction of "unnecessary" photos and material by P. N. Milyukov. S. Chernov declined the offer and told about it in the media. A scandal broke and spread to the pages of French and Serbian press. ${ }^{72}$

The activity of the Commission can be estimated as a failure because the "data" were mainly provided only by Bulgarians and partially by Turks. The main cause of it, of course, was P. N. Milyukov as due to his shameless participation, the Commission was expelled from Athens and Belgrade. After those events, the inquiry lost even visibility of objectivity. A talented Russian journalist of the early $20^{\text {th }}$ century V. M. Doroshevich not without reason called the perpetual assistant professor P. N. Milyukov "the god of tactlessness". ${ }^{73}$

The Commission Report cannot be observed as an objective study. It can be considered only as a relic of propaganda wars of the early $20^{\text {th }}$ century, one of the first attempts to use non-governmental organizations for achieving quite distinct interests of certain states. At the same time, even an applied propaganda value of the Report published in 1914 was insignificant. Owing to slowness of transport, information and technical means, the idea of paymasters of the Report had lost its urgency. After the beginning of WWI Serbia became a "useful" victim, and the Central powers became enemies. Carnegie Endowment actively helped restoring the libraries in Serbia damaged by the Austrian bombing of Belgrade. Nevertheless, the money for publishing Report was not spent in vain. The book languished in the dark corners of libraries waiting in the wings. In the 1990s, the Serbs became "the main bad guys" in Europe once again. Dust was blown off from the old volume; it was reissued on expensive

72 Н., „Миљуков на послу“, Политика, 3531, 10. 11. 1913, 1; Аноним, „Г. Чернов у Београду“, Политика, 3537, 16.11.1913, 2.

73 Иосиф И. Колышко, Великий распад: Воспоминания, (Санкт-Петербург: НесторИстория, 2009), 563. 
thick paper with hardcover for use in new media wars to support the idea that the tragedy of Srebrenica had historical roots in Serbian past.

The Report was reissued in a genre of "gray propaganda" as a reprint without the data on publishers and was distributed for free or for nominal price. However, except a media war weapon and propaganda key, the benefit of this reprinting is questionable. Violation of war laws by all countries-participants of the Balkan Wars (Serbia, Montenegro, Bulgaria, Greece, Romania, and Turkey) as well as by Albanian insurgents is a very serious subject that deserves careful and attentive studying. It might flash light on the roots of mutual intolerance of the Balkan people and of their conflicts in the world wars of the $20^{\text {th }}$ century, and at the turn of the $20^{\text {th }}$ and $21^{\text {st }}$ centuries. The propaganda works covered by authors' titles and names lead only to the relativisation of events, devaluated memory of the victims and, as a consequence, caused recurrence of the conflicts. One side becomes confident in its sinless innocence and in the right (or even the need) to take revenge; the other side ceases to believe any information about its own involvement into war crimes which also gives a free hand to extremists in or without uniforms. All these eventually results in new rounds of the conflicts and recurrence of tragedies on a larger scale. Perhaps this is the purpose of those who "sympathetically" reopen almost healed old sores of the past of the Balkan peoples?! If, a century ago, the paymasters of the Commission work had only wished to mount an honest and credible investigation of violations of war laws just on the basis of boundless respect for a human life, they could easily have done it even without going into the "Balkan Far-Far-Away." For example, it was possible to conduct the inquiry in the Philippines, where the suppression of the uprising for independence was waged with crimes against humanity, and some events (such as the massacre in Samar) were far crueler than anything committed by the participants of the Balkan Wars. ${ }^{74}$

74 The official US army point of view about mass execution of civilians in Samar on Philippines in 1901 (while Root was at the head of the US Department of Defense) is not roundabout. "The indiscriminate violence and punishment that US Army and Marine forces under Brig. Gen. Jacob Smith are alleged to have unleashed on Samar have long stained the memory of the United States' pacification of the Philippine Islands". Charles Hendricks, "Editor's Joyrnal", Army History Bulletin, PB 20-11-2 (No. 79), 2. Filipinos speak even more directly: "In their desperation, the American soldiers turned arsonists burning whole towns in order to force guerrillas to the open. One such infamous case of extreme barbarity occurred in the town of Balangiga, Samar, in 1901-1902". Teodoro C. Agoncillo, History of the Filipino People, (Qyezon City: Garotech Pyblishing, 1990), 228. 


\section{Sources and Literature}

Published sources

- International Commission to Inquire into the Causes and Conduct of the Balkan Wars. Washington (DC): Carnegie Endowment for International Peace, 1914.

- Милетич, Любомир. Вардарска Македония - Гръцките жестокости в Македония през Гръцко-българската война. София: Държавна печатница, 1913.

- Милетич, Любомир. Разорението на тракийските българи през 1913 година, Българска академия на науките. София: Държавна печатница, 1918.

Newspapers

- Вечерње новости

- Политика

- Правда

- Самоуправа

Memoirs

- Ангел, Хенрик. Када се један мали народ бори за живот, Српске војничке приче. Београд: Итака, 1995.

- Васић, Драгиша. „Карактер и менталитет једног покољења“. In: Одабрана дела. Београд: Altera, 1990.

- Колышко, Иосиф И. Великий распад: Воспоминания. Санкт-Петербург: Нестор-История, 2009.

- Милюков, Павел Н. Воспоминания (1859-1917). Москва: Политиздат, 1991.

- Савинков, Борис В. Воспоминания террориста. Ленинград: Лениздат, 1990.

- Штрандтман, Василий Н. Балканские воспоминания. Москва: Книжница, 2014.

\section{Literature}

- Abramowitz, Morton. Preface, "The Other Balkan Wars". In: A 1913 Carnegie Endowment Inquiry in Retrospect with a New Introduction and Reflections of the Present Conflict by George Kennan. Washington (DC): Carnegie Endowment for International Peace, 1993. 
- Agoncillo, Teodoro C. History of the Filipino People. Quezon City: Garotech Publishing, 1990.

- Akhund, Nadine. "An Unexpected Outcome of the Balkan Wars: The Carnegie Report of 1913". Балкански ратови 1912-1913: Нова виђења и тумачења. Београд: Историјски институт Институт за стратешке студије, 2013.

- Arnold, James R. The Moro War: How America Battled a Muslim Insurgency in the Philippine Jungle, 1902-1913. London, New York: Bloomsbury Press, 2011.

- Bal, Idris. Turkish Foreign Policy in Post Cold War Era. Boca Raton (Flo.): Brown Walker Press, 2004.

- Brailsford, Henry N. Macedonia, its races and their future. New York: Arno Press, 1906.

- Brailsford, Henry N. The Broom of the War-god: A Novel. London: William Heinemann, 1898.

- Campbell, Cyril. The Balkan Wars Drama. New York: McBride, Nast \& Co., 1913.

- Despot, Igor. The Balkan Wars in the Eyes of the Warring Parties: Perceptions and Interpretations. Bloomington (IN): iUniverce, 2012.

- Finley, John P. "The Mohammedan Problem in the Philippines". The Journal of Race Development, Vol. 5, No. 4 (Apr., 1915).

- Grumel-Jacquignon, François. La Yugoslavie dans la stratégie française de l'Entre-deux-Guerres (1918-1935): aux origines du mythe serbe en France. Bern: Peter Lang, 1999.

- Hendricks, Charles. “Editor's Journal”. Army History Bulletin, PB 20-112 (No. 79).

- Judah, Tim. The Serbs: history, myth and the destructuion of Yugoslavia. London: Yale University Press, 1997.

- Justin, McCarthy. Death and exile: the ethnic cleansing of Ottoman Muslims: 1821-1922. Princeton: Darwin press, 1995.

- Larson, Erik. In the Garden of Beasts: Love, Terror, and an American Family in Hitler's Berlin. New York: Crown Publishing Group, 2011.

- Leventhal, Fred M. The Last Dissenter: H. N. Brailsford and His World. Oxford: Clarednon Press, 1985.

- Mackay, James A. Little Boss: Life of Andrew Carnegie. Edinburgh: Mainstream Publishing, 1997.

- Malcolm, Noel. Kosovo: a short history. London: Papermac, 1998

- $\quad$ Mayers, David. The Ambassadors and America's Soviet Policy. London: Oxford University Press, 1977. 
- Simić, Predrag. "Balkans and Balkanisation: Western Perceptions of the Balkans in the Carnegie Commission's Reports on the Balkan Wars from 1914. to 1996". Perceptions, Summer 2013, Volume XVIII, Number 2, 113-134.

- Todorova, Maria. Imagining the Balkans. New York: Oxford University Press, 1997.

- Vickers, Miranda. The Albanians: a modern history. New York: St. Martin's Press, London: I. B. Tauris, 1995.

- Wilkinson, Henry R. Maps and Politics: A Review of the Ethnographic Cartography of Macedonia. Liverpool: University Press, 1951.

- Бјелајац, Миле. „Провоцирање 'хуманитарне интервенције' против Србије 1913“. Балкански ратови 1912-1913: Нова виђења и тумачења. Београд: Историјски институт Институт за стратешке студије, 2013.

- Макушин, Александр В., Павел А. Трибунский. Павел Николаевич Милюков: труды и дни (1859-1904). Рязань: Частный изд. П. А. Трибунский, 2001.

- Пять этнографических карт Македонии с текстом П. Н. Милюкова. Санкт-Петербург: Издание Школьной Картопечатни, 1900.

- Ружесковић, Саша. „Трагом Самсона Чернова“, Весник. Часопис за историју, музеологију и уметност 38/2011.

- Русское зарубежье. Золотая книга эмиграции. Первая треть ХХ века. Энциклопедический биографический словарь. Москва: Российская политическая энциклопедия, 1997.

- Свирчевић, Мирослав. „Пропаганда против Србије за време Балканских ратова и после њих 1912-1914. године“. Летопис Матице српске $3 / 2013$.

- Энциклопедический биографический словарь. Москва: Российская политическая энциклопедия, 1997. 


\title{
Резиме
}

Алексеј Тимофејев

Милана Живановић

\section{Извештај Карнегијеве комисије о узроцима и начинима вођења балканских ратова 1912-1913. Да ли су аутори извештаја и њихови налогодавци могли да буду објективни?}

\begin{abstract}
Апстракт: Карнегијева комисија о узроцима и начинима вођења балканских ратова 1912-1913. године била је један од првих примера коришћења недржавних организација с циљем стварања „хуманитарних разлога“ како би се извршио притисак на слабе државе које су се појавиле на Балкану пре једног века. Комисија је била група високо плаћених „непристрасних експерата“ за истраживање и објаву резултата, који су унапред били познати странама учесницама конфликта.

Кључне речи: балкански ратови, Карнегијева комисија, пропагандни рат, повреда закона рата
\end{abstract}

На почетку 20. века постојала је идеја о томе да ратови могу бити у потпуности изгнани из људског живота снагом међународних закона и стварањем међудржавних комисија. Идеја мировне комисије била је изузетно популарна међу образованим личностима и технократама. Један од таквих интелектуалаца био је и Ендрју Карнеги. Ипак, његов приступ ситуацији у Европи је био специфичан. На пример, на почетку Првог светског рата Карнеги је сматрао немачког цара Вилхелма најмирољубивијом фигуром старог континента која је достојна поштовања. Први председник Карнегијевог фонда за подршку мира био је Елија Рут, бивши војни министар САД-а, који је 1913. добио Нобелову награду за мир. У периоду Рутовог министровања, од 1899. до 1902, Сједињене Америчке Државе су водиле империјалистички рат против Филипинске републике, који је ујед- 
но био и први који су водиле против устаничког покрета ван граница своје територије.У овом рату савезник САД-а је био османски султан. У таквим условима, значај руског представника у Комисији је порастао с обзиром да је он могао да допринесе да рад целокупне комисије буде перцепиран као објективан. Међутим, П. Н. Миљуков није у томе успео и у очима Београда давао је негативан утисак о Комисији. Још једна контроверзна фигура био је енглески новинар Брејлсфорд, члан Бугарофилског балканског комитета у Лондону. Не само српско, него и грчко непријатељско држање према целој комисији је достигло ниво потпуног бојкота због њених пробугарских погледа. У Бугарској и Турској, пак, Комисија је дочекана пријатељски. Миљуков се присећао: „У Софији наш рад је био организован потпуно другачије него у остале три државе које смо посетили (...) Још раније је значајан део докумената и сведочанстава био припремљен за нас; други део нам је достављен непосредно на наш захтев. Припремни рад је у већој мери обавио мој стари пријатељ, професор Милетић и ја немам ни најмању сумњу у његов одговоран однос и савесност." Извештај Комисије може бити посматран само као последица пропагандних ратова са почетка 20. века и као један од првих покушаја коришћења недржавних организација за остварење прилично различитих интереса одређених држава. 